active at temperatures below $10^{\circ} \mathrm{C}$, so that eggs laid in late autumn may give rise to a generation which matures slowly throughout the winter and emerges in the spring.

Dr. Ll. Lloyd, describing the part played by insects and worms in the disintegration of the biological film in a percolating filter, said that whereas in winter surface growth is usually much in evidence and the medium is slimy throughout the depth of the filter, in summer the same medium often appears perfectly clean. In general, depletion in the quantity of biological film has no effect on the efficiency of the filter.

The effect of film depletion is reflected in the behaviour of the flies, and a very good example is afforded by the study of species of Psychoda at Leeds. Here the number of $P s$. severini reaches a peak in May but is small at any other time of the year. Ps. alternata shows a peak in June which is followed by a steady decline, and the sequence is then taken up by Spaniotoma minima, which builds up an enormous population in the autumn. If the supply of food is sufficient, all three species will breed abundantly from spring to autumn; curtailment of the food supply tends to restrict development, the species which predominates depending on factors which give it a seasonal advantage over its competitors. Introduction of midges (Metriocnemus species) introduces a complicating factor. Although essentially grazers on film, they take readily to a predatory habit and when present they tend to restrict the numbers of the three species of flies just mentioned.

There is also some evidence that food supply affects the size of flies. In the absence of other factors, size depends on temperature, wing-length increasing by about 2 per cent for each fall of $1^{\circ} \mathrm{C}$. in later larval life. In fact, however, the steady increase due to this factor in the size of flies emerging from August onwards shows periodic interruptions which suggest the effect of shortage of food.

Mr. F. T. K. Pentelow said that the effects of pollution on fisheries may result from damage either to the fish themselves, to their spawn or spawning ground, or to their food. Conclusions from toxicity experiments are complicated by the fact that toxicity is greatly affected by the concentration of such sub. stances as calcium in the diluting water, by the concentration of dissolved oxygen, and by the temperature. An idea of the toxicity of different substances is given by the following figures, which express, in parts per million, the concentrations found to be toxic to trout under average conditions : cyanide, 0.15 ; sulphide, $1 \cdot 0$; chlorine, 0.2 ; phenol, 9.0 ; sulphuric acid, 10.0 ; para-cresol, 6.0 ; 1.2 .6 xylenol, 10.0 ; the toxicity, to sticklebacks, of copper is about 0.02 and of zine about 0.3 .

The mode of action of poisons varies widely. Cyanide, for example, destroys the enzyme responsible for transferring oxygen from the blood to the tissues, phenols and cresols appear to be nerve poisons, and heavy metals prevent respiration by coagulating the mucus over the body and gills. With some poisons the toxic action is reversible, affected fish recovering after transference to fresh water, but with other substances it is not. Thus, a shoal of fish subjected to the action of phenol from a temporary discharge of gas liquor might easily recover if the current carried them to a zone of cleaner water, but fish affected by discharge of chlorine or ammonia in similar circumstances would die. The behaviour of fish towards a particular substance is no criterion of its toxicity. They will, for example, keep strictly away from waters containing the less toxic zinc salts, but are so indifferent to the presence of the highly toxic copper salts that they are rapidly killed.

Bacterial oxidation of discharged organic matter results in depletion of oxygen in the river water. Though fish may not be actually asphyxiated until the oxygen content falls to between $0 \cdot 1$ and 0.2 part per 100,000, in practice it is frequently found that fish are absent from waters in which pollution has reduced the value to about 0.5 part per 100,000 .

The effect of pollution on spawn and spawning grounds is almost unknown territory, but more is known about its effect on fish food. In general, pollution of streams by organic matter frequently results in replacement of the characteristic flora and fauna by other types, but without necessarily reducing the total quantity of material acceptable to fish as food. Pollution by inorganic substances is a very different matter. For example, discharge of copper wastes to a stream has been known to render it unable to support the life of trout, even in zones downstream where the concentration of copper is much too small to be directly toxic ; this is because the copper has destroyed the animal life on which carnivorous fish like trout depend.

\section{THE ROYAL ACADEMY, 1948}

\section{BY DR. A. TINDELL HOPWOOD British Museum (Natural History)}

COCRATES once likened books to pictures because, "the creatures of the latter art stand before you as if they were alive, but if you ask them a question, they look very solemn and say not a word". To an argumentative old man the lack of response was deplorable; but to the pictures themselves, had they been sentient, it would assuredly have been the height of wisdom. Many a canvas would be covered with confusion, and mantled with blushes, were it suddenly to be faced by Socrates and to hear the dread question, "Why were you painted ?" Imagine the unease of the self-confessed pot-boiler, the tearful admission of the failures, and the venomous hatred of the shams. No, it is just as well that pictures cannot reply in words. On the other hand, our questions are not left entirely unanswered; but some degree of skill is needed to decipher the very solemn faces masking the replies.

Now, morally there is nothing wrong with an honest pot-boiler. A certain snobbish section of the public is only too ready to repeat hollow phrases about 'art for art's sake', without pausing to reflect that artists, like other men, must eat. Provided that the painter of a pot-boiler has the pride proper to a good craftsman, he plays a useful part in life, even though he does not produce a masterpiece. After all, and we may just as well admit it, none of the great masters of the past, not even Rembrandt or Turner, was consistently inspired; many a picture to which a famous name is attached is to be valued for its craftsmanship rather than for its genius. So let us praise honest craftsmanship wherever we find it, rather than indulge in unkind sneers at the unfortunate whose inspiration has forsaken him for a while. 
Failures and shams are another matter; each reflects upon the character of its author. The failure exposed to public view argues a lack of that sensitivity which is necessary for the recognition that success has eluded one's efforts. As for the painters of shams, it can only be hoped that their spirits may meet with Socrates in the shades: that were punishment infinitely worse than the torment reserved by Dante for the hypocrites.

Why all this ? Well, it's a dull Academy this year, and I do not like dull academies. Good ones are exhilarating, bad ones can be interesting; but dull ones are just dull. Perhaps the hanging is not quite up to standard, and the hanging can make or mar an exhibition. Indeed, the skill and knowledge needed to hang a single wall well, let alone a whole room, seldom receive the recognition which is their due. As a rule, visitors are so busy with the details that they spare no thought for the whole. On the other hand, every experienced gallery-goer has memories, either of good pictures spoiled by bad hanging, or of mediocre pictures vastly improved by good hanging.

Some may remember a certain north wall in one of the Academy's own rooms that was a masterpiece of the hanger's skill a few years ago; two pictures, which normally would have been pushed into a quiet corner, were put in the very centre of the wall, and their sophisticated crudity of colour allowed to lose itself among pictures of an entirely different type and key. The arrangement of that wall revealed the touch of a master; but this year it seems that some of the best pictures are overshadowed, perhaps outshone would be the better word, by the stronger colour of less meritorious neighbours.

The first thing to strike the eye as one ascends the staircase is a curious, whitish, skeletonized structure dominating the Central Hall; actually it is a ferroconcrete version of Bellerophon astride Pegasus, but it also serves to suggest that we begin with the sculpture for a change. Two portraits are of particular interest. One is "Sir Alexander Fleming, F.R.S.", by E. Roland Bevan, and the other "The Viscount Nuffield", by Maurice Lambert. This latter is remarkable for the skill with which the problem of combining originality of treatment with the conventions of formal statuary has been solved; as proof of the sculptor's versatility there is "Starbird" in the South Room. The Lecture Room contains many pleasant pieces; among them are several good figures of animals. "Hunting Leopard" and "Cheetah", both by Pamela Ascherson, "Friesian Bull" and "Complacent Cat", by Marjorie Drawbell, "Cat" by Richard Garbe, and "Falcon" by John M. Luxmore, are only a random selection.

The Lecture Room leads into Gallery IX, the black-and-white room, which contains four drawings of antelopes by Frank Dobson, those of the "Kenya Impala" and the "Black Buck" being particularly good. Barbara Greg's pen and wash drawing of "Adelaide Crescent, Hove", which hangs a few feet away, deserves a better place than it occupies at present. Her woodcut, "A Meeting of the Hell-fire Club", is less successful.

As a rule the Architectural Room contains smaller pictures by lesser lights; but this year there is an imposing array of academicians to keep them company and to spur them on to greater efforts. Here hang "The Blue Sitting Room, Trent Park" by Winston S. Churchill, and "Herrings and Lobster" by Edward le Bas, as well as "Kippers" by Robert H. Hurdle- a newcomer, I think-whose "Round Table: Still Life" in Gallery IV is one of the best pictures of its type in the exhibition.

Of the younger artists, as I judge them to be, Lionel Miskin (No. 30) and Kenneth Martin (No. 42) seemed to be the best in the first room, and Ernest Sandoe (No. 35) is better this year than last. In Gallery II "The Interval", by Jean Primrose, more than maintains the high level of her pictures last year ; "Bannockburn", by Colum Gore-Booth, also deserves a word of praise.

Gallery III is, of course, the main room, and one does not expect many beginners to grace its walls; but two pictures by less well-known painters ought to attract favourable attention; they are "A Present from Provence", by Enid Solomon, and "The Bay", by Adrian Hill. Mr. Churchill's "Blenheim Tapestries" is not so satisfying as his "Goldfish Pool, Chartwell", in the previous room. In portraiture, Henry M. Carr vies with Sir Gerald Kelly, pitting his "F.-M. The Viscount Alexander of Tunis" against the latter's "Sir Malcolm Sargent": one feels that each was completely absorbed in his sitter.

Among paintings in other rooms are "The Fiddler", by Violeta Janes, and "Copying at the National Gallery", by Douglas Mays, both in Gallery V. Apparently this is the first time Miss Janes has exhibited, whereas Mr. Mays, who is 'on the line', made his first appearance last year.

The water-colours, in the South Rooms, are an attractive and varied display. Vivian Pitchforth and John Nash are a continuing inspiration to many, though few come anywhere near them in execution or content. Of the others, I particularly liked "Suffolk Landscape", by Rowland Suddaby, Dorothea Maclagan's flower pieces, "Haze Lifting, Newhaven", by Hadley Rowe, "Propeller Stacks, Deptford Creek", by Innes Meo, and "Cotswold Landscape", by Elizabeth Sorrell.

\section{OBITUARIES}

\section{Dr. H. W. Richmond, F.R.S.}

Herbert William Richmond, the eminent geometer, died of heart failure in the Evelyn Nursing Home, Cambridge, on April 22, at the age of eighty. four. At the time of his death he was senior fellow of King's College, Cambridge, where he had resided almost continuously for sixty-five years. The only substantial break in this long period of residence was during the First World War, from 1916 until 1919, when he worked at ballistics at Portsmouth with A. V. Hill and the late Sir Ralph Fowler; during this period he helped to make important contributions on the effects of winds on high-angle trajectories and the effects of spin on the motion of a shell. The lastmentioned work was done in conjunction with R. $H$. Fowler, E. G. Gallop and C. N. H. Lock; it was published in the Philosophical Transactions of the Royal Society, and afterwards became a classic. After the War he edited at Cambridge the confidential "Text-Book of Anti-Aircraft Gunnery", Vols. 1 and 2.

Richmond was born on July 17, 1863, at Tottenham (Middlesex), at Draper's College, of which his father, the Rev. Wm. Hall Richmond, was headmaster. He was educated at Merchant Taylors' School (1875-82), and went up to King's College, Cambridge, in 1882 